\title{
Red Sokoto goats performed well with high nutrient digestibility and nitrogen retention when fed with two varieties of cowpea haulm
}

*11Bala, A. G., ${ }^{2}$ Hassan, M. R., ${ }^{3}$ Amodu, J. T., ${ }^{3}$ Tanko, R. J., ${ }^{1}$ Hassan, A. H., ${ }^{1}$ Bature, M. S., ${ }^{1}$ Mohammed, A and ${ }^{1}$ Alhabib, I. K.

${ }^{\prime}$ Division of Agricultural Colleges, College of Agriculture and Animal Science, Ahmadu Bello University, Mando, Kaduna State, Nigeria.

${ }^{2}$ National Animal Production Research Institute, Ahmadu Bello University, Shika-Nigeria.

*Corresponding author: balaaminu@gmail.com; agbala@abu.edu.ng;

Abstract $+2348068928548$

A study was carried out to investigate the effect of feeding two varieties of cowpea haulm on growth performance, nutrient digestibility and nitrogen balance in Red Sokoto bucks. The experiment consisted of 15 Red Sokoto bucks of average weight of $10 \mathrm{~kg}$, which were balanced for weight and randomly assigned to three dietary treatments with five bucks per treatment in a complete randomize design. The three treatment diets consisted of Brachairia decumbens hay as basal diet and concentrate diets which were supplemented with cowpea haulms at $0 \%$ (Control), 10\% (SAMPEA 14) and 10\% (SAMPEA 15). The study lasted for 90 days. Total dry matter intake (TDMI, g/day), total weight gain (TWG, $\mathrm{kg}$ ), faecal (unit) and urine (unit) outputs were recorded. Results indicated that the TDMI were different $(P<0.05)$ with higher intake (237.64 g/day) in bucks fed control diet, followed by $223.00 \mathrm{~g} /$ day 10\% SAMPEA 15 and $10 \%$ haulm of Sampea 14 (206.49g/day) in the concentrate. The TWG and average daily weight gain increased by $59.77 \%$ and $59.76 \%$, respectively with respect to $10 \%$ SAMPEA 14 haulm inclusion compared to the control diet. The digestibilities of dry matter (DM), crude protein $(C P)$, crude fibre (CF), ether extract (EE) and nitrogen free extract (NFE) were higher $(P<0.05)$ in bucks fed diet constaining 10\% SAMPEA 14 inclusion level compared to the treatment diets. The quantity of $N$ retained by the bucks was higher $(P<0.05)$ with the inclusion of 10\% of SAMPEA 14 (3.79 g/day) compared to those fed 10\% SAMPEA 15 (1.18 $\mathrm{g} /$ day) and the control diet $(0.68 \mathrm{~g} /$ day). It is concluded that farmers should include $10 \%$ SAMPEA 14 in concentrate diet of Red Sokoto bucks for optimum performance under smallholder production system.

Keywords: Cowpea, Digestibility, Performance, Varieties, Haulm

Les chèvres Rouges Sokoto ont obtenu de bons résultats avec une digestibilité élevée des nutriments et une rétention d'azote lorsqu'elles sont nourries avec deux variétés

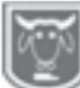

des haulms de niébé

\section{Résumé}

Une étude a été menée pour étudier l'effet de l'alimentation de deux variétés des haulms de niébé sur la performance de croissance, la digestibilité des nutriments et l'équilibre azoté chez les mâles Red Sokoto. L'expérience s'est composée de 15 bucks rouges de Sokoto de poids moyen de $10 \mathrm{~kg}$, qui ont été équilibrés pour le poids et aléatoirement assignés à trois traitements diététiques avec cinq dollars par traitement dans une conception randomize complète. Les trois régimes de traitement se sont composés deBrachairiadecumbenshay comme régime basal et régimes concentrés qui ont été complétés avec des haulms de niébé à $0 \%$ (contrôle), 10\% (SAMPEA 14) et 10\% (SAMPEA 15). L'étude a duré 90 jours. La 


\section{Red Sokoto goats performed well with high nutrient digestibility and nitrogen retention}

consommation totale de matière sèche (TDMI, g/day), le gain de poids total (TWG, $\mathrm{kg}$ ), les sorties fécales (unitaires) et urinaires (unitaires) ont été enregistrées. Les résultats ont indiqué que le TDMI était différent $(P<0,05)$ avec une consommation plus élevée $(237,64$ g/jour) dans le régime de contrôle alimenté par les mâles, suivi de 223,00 g/jour10\% SAMPEA 15 et 10\% de transport de Sampea 14 (206,49 g/jour) dans le concentré. Le TWG et le gain quotidien moyen de poids ont augmenté de 59,77\% et de 59,76\%, respectivement en ce qui concerne l'inclusion de $10 \%$ de SAMPEA 14 haulms par rapport au régime de contrôle. Les digestibilités de la matière sèche (le 'DM'), des protéines brutes (le ' $\left.C P^{\prime}\right)$, des fibres brutes (le 'CF'), de l'extrait d'éther (le 'EE') et de l'extrait sans azote (le 'NFE') étaient plus élevées $(P<0,05)$ chez les mâles nourris à l'alimentation constaining 10\% SAMPEA 14 niveau d'inclusion par rapport aux régimes de traitement. La quantité de $N$ retenue par les mâles était plus élevée $(P<0,05)$ avec l'inclusion de 10\% de SAMPEA 14 (3,79 g/jour) par rapport à celles nourries $10 \%$ SAMPEA 15 (1,18 g/jour) et le régime de contrôle (0,68 $\mathrm{g} /$ jour). Il est conclu que les agriculteurs devraient inclure 10\% SAMPEA 14 dans le régime concentré de bucksRed Sokoto pour une performance optimale dans le cadre du système de production des petits exploitants.

Mots-clés: Cowpea, Digestibility, Performance, Variétés, Haulm

\section{Introduction}

Livestock is an important component in the agricultural production system, and plays a crucial role in the economy (Hasan et al., 2010). The role of livestock in providing protein is essential in human nutrition and it is increasingly being recognized. This necessitates immediate concern in development programs for improvement of livestock productivity, through improved nutrition. However, feed constraint is the most important limiting factor in livestock production (Aregawi et al., 2013). In Nigeria, the dietary energy (2.4 $\mathrm{Mcal} / \mathrm{kgDM}$ ) and protein (5.6\%) obtained from rangelands, particularly in the dry season are generally too low to meet the nutrient requirements of ruminant livestock for maintenance $(2.7 \mathrm{Mcal} / \mathrm{kgDM}$ and $11.6 \% \mathrm{CP}$ ) and production (2.9 Mcal $/ \mathrm{kgDM}$ and $16.2 \% \mathrm{CP})$ (NRC, 1985). Animal productivity could be increased by the introduction of low cost technologies such as feeding systems that are simple, consistently practical and within the limits of the farmer's resources (Douthwaite, 2002). One of such feeding systems is the use of cowpea haulm that supplies protein in fodder for livestock (FAO, 2000). Coker et al. (2014) emphasized the importance of cowpea forage as animal feed mainly during the dry season. Cowpea haulm addition improves nutrient supply and growth of livestock over the use of low quality forages alone (Antwi et al., 2014). Previous studies by Anele et al. (2010) indicated that cowpea (Vigna unguiculata L. Walp) haulm can be utilized as a supplement for ruminants in the dry season. Similarly, Osafo et al. (2013) observed improved intake and digestibility of poor quality fodder with supplementation of cowpea haulm. The incorporation of promising legumes fodder such as cowpea haulms for livestock production will help to overcome the feed shortages. The Institute for Agricultural Research (IAR), Zaria with other collaborating institutes has bred and released new cowpea varieties overtime with focus mostly on higher grain yield while forage yield and quality is rarely a priority (Pande et al., 2003). SAMPEA 14 and 15 varieties of cowpea are high yielding, striga resistant and tolerant to heat and drought with maturity period of 70-78 days (IAR, 2015). Considering the good qualities of this legume crop in the tropical 
savanna, the knowledge of its nutritive value will be very important. This study was therefore, designed to investigate the effect of feeding two cowpea haulm varieties on growth performance, nutrient digestibility and nitrogen balance in Red Sokoto bucks.

\section{Materials and methods}

\section{Experimental site}

The feeding trial and nutrient digestibility study was conducted at the Sheep and Goat Unit of College of Agriculture and Animal Science, Division of Agricultural colleges, Ahmadu Bello University, Mando-Road, Kaduna State. The farm is located at an elevation of $676 \mathrm{~m}$ and latitude of $10^{\circ} 35^{\prime} \mathrm{Nand}$ longitude of $7^{\circ} 25^{\prime} \mathrm{E}$ (GPS, 2018).

\section{Sources of experimental materials}

Cowpea haulms (SAMPEA 14 and 15 varieties), Brachiaria decumbens hay (signal grass) and Red Sokoto bucks were obtained from Pasture Unit and Sheep and Goat Unit of College of Agriculture and Animal Science, Ahmadu Bello University, Mando-Kaduna State, Nigeria.

\section{Experimental design and animal's} management

Fifteen experimental Red Sokoto bucks of an average weight of $10 \mathrm{~kg}$ were used for the experiment. The animals were balanced for initial weights before they were allocated to three treatment diets with five bucks per treatment in a Complete Randomize Design (CRD). The bucks were de-wormed with Albendazole by oral administration against internal parasites, Rhodiacides solution was sprayed on the animals using knapsack sprayer against external parasites. The animals were allowed 14 days to adjust to feed and confinement before the actual start of the experiment that lasted for 90 days.

Experimental feeds, treatments and feeding trial

The three treatment diets consisted of Brachiaria decumbens hay as basal diet. Concentrate diets $(14 \% \mathrm{CP})$ was supplemented with cowpea haulms at $0 \%$ (Control), 10\% (SAMPEA 14) and 10\% (SAMPEA 15). The supplemented concentrate consisted of other ingredients such as maize offal, cottonseed cake, bone meal and salt. The basal forage diet was fed ad libitum after feeding the supplements in order to ensure maximum supplement consumption at the rate of $1 \%$ of body weight per head per day in the morning (08:00 am). Water and mineral salt lick were provided ad libitum for the period of 90 days. All bucks were weighed at the beginning of the experiment and fortnightly thereafter, to determine the liveweight changes and to adjust the amount of feed offered in order to maintain the predetermined level of $3 \%$ feeding of the animal's body weight for the periods in confinement.

\section{Measurement of growth performance}

Weekly feed intake (g/day), weight gain (kg) and feed conversion ratio were determined. Feed intake was obtained by the difference between supplied feed and feed left in each pen. Weight gain was determined as the difference between the weight of the animal at the beginning of the experiment and subsequently at two weeks intervals. Feed conversion ratio was obtained as the ratio of feed intake and weight gain within each week for each pen.

Digestibility and nitrogen retention study

At the end of the feeding trial, three animals were randomly selected from each of the three treatment groups and housed in metabolic creates for total faecal and urine collection as described by Osuji et al. (1993). The bucks were maintained on the same treatment diets used in the feeding trial and were allowed 14 days adjustment period before the start of the digestibility studies. Each morning (8.000am), feed left over, faecal output and urine output were collected and weighed for seven days. The daily total faecal output collected form each 
buck was weighed, bulked and sub-sample was taken for analysis. The daily urine output from each buck was collected into a plastic container containing $10 \mathrm{~mL}$ of $0.1 \mathrm{M}$ $\mathrm{H}_{2} \mathrm{SO}_{4}$ placed under the metabolic creates to prevent nitrogen loss by volatilization. Urine collected was bulked and about 10\% of the total urine output was subsampled for each buck and stored in the refrigerator pending nitrogen determination.

\section{Laboratory analysis}

Feed samples offered, feed left over and faecal output were analysed for chemical compositions, urine samples were analyzed for nitrogen using the method described by AOAC (2005) at the central laboratory of
National Animal Production Research Institute, Shika-Kaduna. Metabolizable Energy (ME) of the diet was estimated using the equation of Alderman (1985):

$\mathrm{ME}(\mathrm{MJ} / \mathrm{kg} \mathrm{DM})=11.78+0.00654 \mathrm{CP}+$ $(0.000665 \mathrm{EE})^{2}-\mathrm{CF}(0.00414 \mathrm{EE})-$ $0.0118 \mathrm{~A}$

\section{Statistical analysis}

Data collected were analysed using Analysis of Variance (ANOVA) by General Linear Model procedures (SAS, 2003). Data on rumen metabolites and weight changes were analyzed using repeated measures ANOVA and trend analysis. Treatment means were separated using Dunnet's Test.

\section{Results}

Table 1: Ingredient composition of concentrates containing cowpea haulms supplements

\begin{tabular}{lccc}
\hline & & \multicolumn{2}{c}{ cowpea haulm variety } \\
\cline { 3 - 4 } Parameter & CONTROL $(0 \%)$ & SAMPEA 14 $(10 \%)$ & SAMPEA 15 (10\%) \\
\hline Cowpea haulm & 0.00 & 10.00 & 10.00 \\
Maize offal & 35.46 & 27.33 & 31.08 \\
Rice offal & 30.00 & 30.00 & 30.00 \\
Cottonseed cake & 32.54 & 30.67 & 26.92 \\
Bone meal & 1.50 & 1.50 & 1.50 \\
Common salt & 0.50 & 0.50 & 0.50 \\
Total & 100.00 & 100.00 & 100.00 \\
Cost/ kg feed (\$) & 72.29 & 61.76 & 58.22 \\
Calculated analysis: & & & \\
Crude protein (\%) & 14.46 & 14.19 & 14.41 \\
M.E (Kcal/kg) & 3090 & 3059 & 3051 \\
\hline ME = Metabolizable energy, ${ }^{\circ}=$ Naira & &
\end{tabular}

Table 2: Chemical composition of two varieties of cowpea haulm and Brachiaria decumbens

\begin{tabular}{lccc}
\hline & \multicolumn{2}{c}{ cowpea haulm variety } & \\
\cline { 2 - 3 } Parameters (\%) & SAMPEA 14 & SAMPEA 15 & Brachiaria decumbens hay \\
\hline Dry matter & 89.66 & 88.52 & 87.39 \\
Crude protein & 16.11 & 15.55 & 7.31 \\
Crude fibre & 27.88 & 28.50 & 28.8 \\
Ether extract & 1.83 & 1.55 & 0.93 \\
Nitrogen Free Extract & 47.34 & 51.48 & 42.18 \\
Ash & 5.28 & 5.88 & 5.14 \\
Neutral detergent fibre & 59.97 & 61.4 & 62.06 \\
Acid detergent fibre & 34.03 & 35.3 & 30.76 \\
Lignin & 17.18 & 18.4 & 7.21 \\
\hline
\end{tabular}


The result presented in Table 3 showed the effect of feeding two varieties of cowpea haulm on growth performance of Red Sokoto bucks fed Brachiaria decumbens hay as basal diet. Treatments diet with $10 \%$ SAMPEA 14 haulm inclusion resulted in significantly higher $(\mathrm{P}<0.05)$ final weight gain $(12.31 \mathrm{~kg})$ compared to the control $(10.65 \mathrm{~kg})$ and $10 \%$ SAMPEA $15(10.94 \mathrm{~kg})$ in the concentrate. Treatments diet with $10 \%$ SAMPEA 14 resulted in significantly higher $(\mathrm{P}<0.05)$ total weight gain $(2.61 \mathrm{~kg})$ compared to the control $(1.05 \mathrm{~kg})$ and $10 \%$ SAMPEA $15(1.09 \mathrm{~kg})$ in the concentrate which were similar. However, treatments diet with $10 \%$ SAMPEA 14 resulted in higher $(\mathrm{P}<0.05)$ average daily weight gain $(29.00 \mathrm{~g})$ compared to the control $(11.67 \mathrm{~g})$ and $10 \%$ SAMPEA $15(12.11 \mathrm{~g})$ treatment.

Total weight gain and average daily weight gain increased by $59.77 \%$ and $59.76 \%$, respectively with respect to $10 \%$ SAMPEA 14 haulm inclusion compared to the control diet. Bucks fed 10\% SAMPEA 14 in the concentrate gained statistically higher $(\mathrm{P}<0.05)$ feed conversion ratio (7.12) compared with the control diet (20.36) and 10\% SAMPEA 15 (18.41) treatment diet. Similarly, bucks fed the control diet had the highest supplement and Brachiaria decumbens hay intake of 207.97 and $29.67 \mathrm{~g} /$ day, respectively compared to diets with cowpea haulm varieties. The total dry matter intake was statistically different $(\mathrm{P}<0.05)$ with highest intake $(237.64 \mathrm{~g} /$ day $)$ in bucks fed the control followed by $223.00 \mathrm{~g}$ /day $10 \%$ Sampea 15 while $10 \%$ SAMPEA 14 in the supplement recorded the least $(206.49 \mathrm{~g} /$ day $)$. The dry matter intake increased by $13.10 \%$ with respect to the control diet compared to $10 \%$ inclusion level of SAMPEA 14 cowpea haulm.

Table 4 shows the effect of feeding two cowpea haulm varieties on nutrient digestibility (\%) in Red Sokoto bucks fed Brachiaria decumbens hay as basal diet result of nutrient digestibility study. There were significant $(\mathrm{P}<0.05)$ differences across the treatments in the entire digestibility coefficient. The result showed that the digestibilities of dry matter (DM), crude protein $(\mathrm{CP})$, crude fibre $(\mathrm{CF})$, ether extract (EE) and nitrogen free extract (NFE) were significantly higher $(\mathrm{P}<0.05)$ in bucks fed diet constantly with $10 \%$ SAMPEA 14 inclusion level compared to other treatment diet. Though, the DM, CP, EE and NFE digestibility of bucks fed 10\% SAMPEA 15 diet were at par $(\mathrm{P}>0.05)$ with those fed on the control diet. However, bucks fed the control diet had higher $(\mathrm{P}<0.05)$ Ash digestibility (41.72\%) compared to bucks fed 10\% SAMPEA 14 (32.83\%) and10\% SAMPEA 15 (24.94\%) diets.

Table 3: The effect of feeding two cowpea haulm varieties on growth performance of Red Sokoto bucks fed Brachiaria decumbens hay as basal diet

\begin{tabular}{|c|c|c|c|c|c|}
\hline \multirow[b]{3}{*}{ Parameter } & \multirow{3}{*}{$\frac{\text { CONTROL }}{0}$} & \multicolumn{2}{|c|}{ cowpea haulm variety } & \multirow[b]{3}{*}{ SEM } & \multirow[b]{3}{*}{ LOS } \\
\hline & & SAMPEA 14 & SAMPEA $15(\%)$ & & \\
\hline & & 10 & 10 & & \\
\hline \multicolumn{6}{|l|}{ Body weight change (kg) } \\
\hline Initial & 9.60 & 9.70 & 9.85 & 1.12 & NS \\
\hline Final & $10.65^{\mathrm{b}}$ & $12.31^{\mathrm{a}}$ & $10.94^{\mathrm{ab}}$ & 0.57 & $*$ \\
\hline TWG & $1.05^{\mathrm{b}}$ & $2.61^{\mathrm{a}}$ & $1.09^{\mathrm{b}}$ & 0.68 & $*$ \\
\hline $\operatorname{ADWG}(\mathrm{g} / \mathrm{d})$ & $11.67^{\mathrm{b}}$ & $29.00^{\mathrm{a}}$ & $12.11^{\mathrm{b}}$ & 2.15 & $*$ \\
\hline FCR & $20.36^{\mathrm{b}}$ & $7.12^{\mathrm{a}}$ & $18.41^{\mathrm{b}}$ & 2.10 & $*$ \\
\hline \multicolumn{6}{|l|}{ DM Intake (g/day) } \\
\hline Concentrate & $207.97^{\mathrm{a}}$ & $186.46^{\mathrm{c}}$ & $197.33^{b}$ & 3.23 & $*$ \\
\hline B. ducumbens hay & $29.67^{\mathrm{a}}$ & $20.03^{\mathrm{b}}$ & $25.67^{\mathrm{ab}}$ & 1.26 & $*$ \\
\hline TDMI & $237.64^{\mathrm{a}}$ & $206.49^{c}$ & $223.00^{\mathrm{b}}$ & 3.11 & $*$ \\
\hline
\end{tabular}


Table 4: The effect of feeding two cowpea haulm varietieson nutrient digestibility in Red Sokoto bucks fed Brachiaria decumbens hay as basal diet

\begin{tabular}{lccccc}
\hline & \multicolumn{5}{c}{ cowpea haulm variety } \\
\cline { 2 - 5 } Nutrient Digestibility (\%) & CONTROL & SAMPEA 14 & SAMPEA 15 $(\%)$ & \\
\cline { 2 - 5 } Dry matter & 0 & 10 & 10 & SEM & LOS \\
Crude protein & $51.10^{\mathrm{b}}$ & $75.81^{\mathrm{a}}$ & $54.11^{\mathrm{b}}$ & 1.87 & $*$ \\
Crude fibre & $61.19^{\mathrm{b}}$ & $77.41^{\mathrm{a}}$ & $61.71^{\mathrm{b}}$ & 2.30 & $*$ \\
Ether extract & $63.22^{\mathrm{c}}$ & $86.08^{\mathrm{a}}$ & $72.87^{\mathrm{b}}$ & 1.31 & $*$ \\
Ash & $26.62^{\mathrm{b}}$ & $39.17^{\mathrm{a}}$ & $27.57^{\mathrm{b}}$ & 2.49 & $*$ \\
Nitrogen free extract & $41.72^{\mathrm{a}}$ & $32.83^{\mathrm{b}}$ & $24.94^{\mathrm{b}}$ & 3.03 & $*$ \\
abc Means with different superscripts along the row differed significantly $(\mathrm{P}<0.05)$ SEM = Standard error \\
of means LOS = Level of Significance
\end{tabular}

The effect of feeding two cowpea haulm varieties on nitrogen ( $N$ ) balance in Red Sokoto bucks fed Brachiaria decumbenshay as basal diet is shown in Table 5. There were no significant $(\mathrm{P}<0.05)$ differences in all parameters measured, except for total $\mathrm{N}$ loss and $\mathrm{N}$ retained. Bucks on $10 \%$ SAMPEA 15 and the control diets, had the highest $(\mathrm{P}<0.05)$ total $\mathrm{N}$ loss compared to $10 \%$ SAMPEA 14 diet. The quantity of $\mathrm{N}$ retained by the bucks was higher $(\mathrm{P}<0.05)$ with the inclusion of $10 \%$ of SAMPEA 14 (3.79 g/day) compared to those fed $10 \%$ SAMPEA 15 (1.18 g/day) and the control diet $(0.68 \mathrm{~g} /$ day $)$.

Table 5: The effect of feeding two cowpea haulm varieties on nitrogen balance in Red Sokoto bucks fed Brachiaria decumbenshay as basal diet

\begin{tabular}{|c|c|c|c|c|c|}
\hline \multirow[b]{3}{*}{ Nitrogen balance (g/day) } & \multirow{3}{*}{$\begin{array}{c}\text { CONTROL } \\
0\end{array}$} & \multicolumn{2}{|c|}{ cowpea haulm variety } & \multirow[b]{3}{*}{ SEM } & \multirow[b]{3}{*}{ LOS } \\
\hline & & SAMPEA 14 & SAMPEA $15(\%)$ & & \\
\hline & & 10 & 10 & & \\
\hline Nitrogen intake & 5.07 & 6.43 & 5.46 & 0.68 & NS \\
\hline Faecal Nitrogen & 3.45 & 2.13 & 3.46 & 0.72 & NS \\
\hline Urinary Nitrogen & 0.94 & 0.51 & 0.81 & 0.45 & NS \\
\hline Total Nitrogen Loss & $4.39^{\mathrm{a}}$ & $2.64^{\mathrm{b}}$ & $4.28^{\mathrm{a}}$ & 0.77 & $*$ \\
\hline Nitrogen retained & $0.67^{\mathrm{b}}$ & $3.79^{\mathrm{a}}$ & $1.18^{\mathrm{b}}$ & 0.62 & $*$ \\
\hline Nitrogen absorbed & 1.61 & 2.80 & 1.68 & 1.11 & NS \\
\hline
\end{tabular}

\section{Discussion}

Bucks fed SAMPEA 14 haulm variety in the supplement gained more weight on daily basis compared to the control treatment and SAMPEA 15 haulm variety in the supplement. The higher average daily weight gain of bucks fed diet containing $10 \%$ level of SAMPEA 14 cowpea haulm variety was most likely due to adequate energy and protein provided, which are critical for the growth of livestock. This can be explained by the fact that the cowpea haulm varieties might have helped to increase the efficiency of utilization of roughages by the rumen microbes which resulted to improved weight gain in mature animals (Karikari and Blasu, 2009). Previous studies by Anele et al. (2010) indicated that cowpea haulm can be utilized as a supplement for ruminants in the dry season. The result of this study is in agreement with previous findings which 
indicated that cowpea haulm in the diets of goats can improve live weight gain and nutrient utilization (Yashim et al. 2016; Tekle et al. 2018). Similarly, dry matter intake was highest in bucks fed the control diet compared to $10 \%$ SAMPEA haulm variety in the supplement. The low intake could be attributed to the nutrient supply of the cowpea haulms in the supplement, thereby satisfying the bucks' nutritional needs at lower intake. This is evidenced in the low feed conversion ratio observed in the two treatments containing Sampea haulm varieties compared to the control. Improve leguminous forages in diets of ruminant livestock help to improve nutrient supply and energy of the diet (Singh et al. 2010; Antwi et al., 2014). This is in contrast to the works of Osafo et al. (2013); Nuwam (2015); Yashim et al. (2016) and Tekle et al. (2018) who reported that cowpea haulm supplementation in concentrate diet of goats improved dry matter intake. The difference could be attributed to the cowpea haulm varieties and level of inclusion in the diets.

The digestibility of dry matter, crude protein, crude fibre, ether extract and nitrogen free extract were found to increase with inclusion of cowpea forage. The most probable explanation for this phenomenon is that diet at $10 \%$ inclusion level of SAMPEA 14 might have resulted in high palatability, increased activity of rumen microorganisms for rapid fibre digestion in the rumen and better utilization of the nutrients by the bucks. The improvement in digestibilities of nutrients might be attributed to the quality of SAMPEA 14 cowpea forage which might have improved the digestibility of other poor quality roughages. The improvement in $\mathrm{CP}$ digestibility due to cowpea hay supplementation could be attributed to the high CP content of the legumes as argued by Umunna et al. (1995) and Murphy and Colucci (1999).
Nitrogen retention $(\mathrm{N})$ is the major indicator for accessing the protein nutritional status of ruminant livestock (Abdu et al., 2012). The N retained recorded in bucks fed $10 \%$ SAMPEA 14 inclusion levels is in agreement with the report of Yashim, (2016) that $\mathrm{N}$ depends on efficient digestibility of nutrients and or utilization. The low $\mathrm{N}$ retention for bucks in the control diet could be due to the inadequacy of the diet to maintain $\mathrm{N}$ equilibrium and, consequently, live-weight gain (Abule et al., 1995). In the study, the significantly higher $\mathrm{N}$ retained and lower $\mathrm{N}$ loss in bucks fed $10 \%$ SAMPEA 14 inclusion levels cowpea forage indicated that, it might contain enough digestible nutrients to provide nutrient retention for better performance in Red Sokoto bucks. However, the better N retention in the diet supplemented with SAMPEA 14 cowpea haulm, could be due to a higher rumen degradable protein available which reduced the total $\mathrm{N}$ losses. Elseed et al. (2005) also, observed that supplementation of protein sources improved microbial $\mathrm{N}$ yield and $\mathrm{N}$ retention.

\section{Conclusion}

From this study, it can be concluded that $10 \%$ SAMPEA 14 in concentrate diet of Red Sokoto bucks improved growth, digestibility and nitrogen retention.

\section{References}

Abdu. S. B., Ehoche, O. W., Adamu, A. M., Bawa, G. S., Hassan, M. R., Yashim, S. M and Adamu, H. Y. 2012. Effect of varying levels of Zizyphus mauritiana) leaf Meal inclusion in Concentrate diet on performance of growing Yankasa Ram lambs fed maize stover basal diet. Iranian Journal of Applied Animal Science 2 (4): 253-256

Abule, E., Umunna, N. N., Nsahlai, I. V., Osuji, P. O. and Alemu, Y. 1995. 
Red Sokoto goats performed well with high nutrient digestibility and nitrogen retention

The effect of supplementing ofEragrostis tef) straw with graded levels of cowpea (Vigna unguiculatal and lablab (Lablab purpureus) hays on degradation, rumen particulate passage and intake by crossbred Friesian $x$ Boran (Zebu) calves. Livestock Production Science, 44: 221-228.

Alderman, G. 1985. Prediction of the energy value of compounds feed. In: W. Haresign and D.J. Cole (eds). Recent Advances In Animal nutrition. Butterworth, London, U.K. 19.

Anele, U. Y., Arigbede, O. M., Sudekum, K. H., Ike, K. A., Oni, A. O., Olanite, J. A., Amole, G. A., Dele, P. A and Jolaosho, A. O. 2010. Effects of processed cowpea (Vigna unguiculata L. Walp) haulms as a feed supplement on voluntary intake, utilization and blood profile of West African dwarf sheep fed a basal diet of Pennisetum purpureum in the dry season. Animal Feed Science Technology. 159 (1-2):10-17

Antwi, C., Osafo, E. L. K., Donkoh, A. and Adu-Dapaah, H. 2014. Chemical composition, gas production and degradation characteristics of haulms of improved dual purpose Cowpea (Vigna unguiculata 1. walp) cultivars. Livestock Research for Rural Development, 26(11): 1-9.

AOAC. 2005. Official Methods of Analysis of Association of Official Analytical Chemist, $17^{\text {th }}$ Edition, Washington D. C., U. S. A.

Aregawi, T., Animut, G. and Kassa, H. 2013. Utilization and nutritive value of sesame (Sesamum indicum L.) straw as feed for livestock in the North western lowlands of Ethiopia. Livestock Research for
Rural Development. (25), 124.

Coker, A. A., Odoemena, B., Akogun, E. O. and Mohammed, D. 2014. Cowpea farming in Mashegu local government area of Niger State: Implications for sustainable production and inclusive growth in Nigeria. Journal of Sustainable Development in Africa, 16 (5): 3348.

Douthwaite, B. 2002. Enabling innovation: a practical guide to understanding and fostering technology change. ZED Books, London \& New York.

Elseed, F. A. 2005. Effect of supplemental protein feeding frequency on ruminal characteristics and microbial $\mathrm{N}$ production in sheep fed treated rice straw. Small Rumininant Research. 57:11-17.

FAO. 2000. FAOSTAT Food and Agriculture Organization of the United Nations, Rome, Italy. Database. http://apps.fao.org.

GPS, 2018. Geo-Positioning System (GPS). Garmin extres 12 channel Garmin.

Hasan, M. R., Akbar, M. A., Khanderkar, Z. H. and Rahman, M. M. 2010. Effect of nitrogen fertilizer on yield contributing character, biomass yield and nutritive value of cowpea forage. Bangladesh Journal of Animal Science, 39:83-88.

IAR. 2015. Released Variety Descriptors. Institute for Agricultural research, Samaru, Federal Ministry of Agriculture and rural Development. Ahmadu Bello University Zaria-Nigeria. Pp 6973.

Karikari, P. K. and Blasu, E. Y. 2009. Influence of nutritional flushing prior to mating on the performance of West African Dwarf Goats mated in the rainy season. Livestock 
Bala, Hassan, Amodu, Tanko, Hassan, Bature, Mohammed and Alhabib

Research for Rural Development.21 (103). Retrieved January 15, 2013

Murphy, A. M and Colucci, P. E. 1999. A tropical forage solution to poor quality ruminant diets: A review of Lablab purpureus. Livestock Research for Rural Development (11): 2

NRC. 1985. National Research Council. Nutrient Requirements of sheep (6th ed.). Subcommittee on Sheep Nutrition, Committee on Animal Nutrition, Board on Agriculture, Nation Research Council, National Academy Press, Washington, D.C. $\mathrm{R}$ e $\mathrm{t} \mathrm{r}$ i e $\mathrm{ved}$ f $\mathrm{r}$ o $\mathrm{m}$ http://www.sheep.cornell.edu

Nuwam, J. 2015. Comparative Study on the Utilization of Groundnut Haulms and Cowpea Husks by Lactating Red Sokoto Does fed Digitaria smutsii Basal Diet.M.Sc. Thesis, Department of Animal Science, Faculty of Agriculture, Ahmadu Bello University, Zaria, Nigeria, Pp 1-82.

Osafo, E. L. K., Antwi, C., Donkoh, A. and Adu- Dapaah, H. 2013. Feeding graded levels of an improved cultivar haulm as supplement for rams fed maize Stover diet. International Journal of Agricultural Research, 8(2):8793.

Osuji, P. U., Nsahli, I. V. and Khalil, H. 1993. Feed evaluation. ILCA manual 5: ILCA, Addis Ababa Ethiopia. 40.

Pande, S. Bandyopa, R. Bliimmel, M. Narayana, R. J. Thomas, D. and Navi. S. S. 2003. Disease management factors influencing yield and quality of sorghum and groundnut crop residues. Field Crops Research, 84: 89-103.
SAS. 2003. SAS/STAT. Guide for personal computer version, $6^{\text {th }}$ Edition. Statistical Analysis System Institute, Inc. Cary, North Carolina, USA.

Singh, S., Nag, S. K., Kundu, S. S. and Maity, S. B. 2010. Relative intake, eating pattern, nutrient digestibility, nitrogen metabolism, fermentation pattern and growth performance of lambs fed organically and inorganically produced cowpea hay-barley grain diets. Tropical Grassland, 44: 5561

Tekle, D. and Gebru. G. 2018. The effect of haulms of groundnut and cowpea supplementations on growth performance of Abergelle goats. Livestock Research for Rural Development. 30 (50). Retrieved December 2, 2019, from http://www.lrrd.org/lrrd30/3/dest3 0050.htmlurl

Umunna, N. N., Osuji, P. O., Nsahlai, I. V., Khalili, H. and Mohamed Saleem, M. A. 1995. Effect of supplementing oat hay with lablab, sesbania, tagaste or wheat middlings on voluntary intake, utilization and weight gain of Ethiopian Menz sheep. Small Ruminant Research, 18: 11201130.

Yashim, S., Gadzama, U. I. and Fwangtu, P. I. 2016. Comparative evaluation of nutritive value of cowpea (Vigna unguiculata) and groundnut (Arachis hypogaea) haulms in the diet of Red Sokoto goats. Adamawa State University Journal of Agricultural Science. 4(2):134144.

Received: $14^{\text {th }}$ October, 2020 Accepted: $5^{\text {th }}$ February, 2021 